\section{Learning disorders related to exposure to general anesthetic in children}

\section{Abstract}

Background: There are many animal studies demonstrating increased neuroapoptose in the first periods of development, especially in stronger neural development regions. In young cobais neuroapoptose also noted, however, more localized area as the dentate nucleus and the olfactory bulb of the brain regions that show sinaptogênse even in adulthood and is responsible for learning.

Objective: To describe the current studies about learning disabilities and cognitive impairment related to exposure to general anesthetics in children.

Method: This is a systematic review, performed from the search in the PubMed database using the keywords "general anesthetics," "neurotoxicity", "children", "young child" and "pediatric" with the criterion inclusion, published in the last five years, in English and related exposure to anesthetics in human children. Were excluded from the articles concerning the studies in experimental animals or that they focus on side effects of other substances on the central nervous system, such as alcohol.

Results: So were found 108 articles. All were analyzed by two researchers individually. Only 27 met the inclusion criteria.

Discussion: In recent years, several studies have been conducted addressing neurotoxicity triggered by general anesthetics. The vast majority using experimental animals or stem cells. Suggest that both inhaled anesthetics such as venous are able to trigger the activation neuroapoptose with release of caspase 3:09, especially in phases of high growth and neural development. There is a strong association
Hermes Melo Teixeira Batista', Woneska Rodrigues Pinheiro", Gylmara Bezerra de Menezes Silveira? Karina Morais Borges ${ }^{1,4}$, Ivo Cavalcante Pita Neto', Miguel Marx², José Lucas Souza Ramos ${ }^{3}$, Italla Maria Pinheiro Bezerra', Vitor Engracia Valentit, Luiz Carlos de Abreu'

1 Laboratory Design and Scientific Writing. Department of Basic Sciences. $A B C$ Faculty of Medicine /Santo André. São Paulo

2 HRC. Juazeiro do Norte .Ceará.

3 FJN. Juazeiro do Norte. Ceará.

4 FFC/UNESP. Marília. São Paulo

\section{Corresponding author:}

Hermes Melo Teixeira Batista

”' hermesmelo@oi.com.br 
between duration of anesthesia and multiple exposures with learning disabilities and behavior.

Conclusion: Currently, you can not say that the damage caused by agents in animals can be replicated humans. However, the severity of outcomes, the FDA recommends avoiding anesthesia and surgery in children under three years, at least those that do not have an emergency basis.

Keywords: Neurotoxicity; general anesthetics; neuroapoptose; learning disabilities; children.

\section{Introduction}

Nowadays, anesthesia is performed everywhere in the world and its development has enabled the surgical approach of patients with increasingly severe conditions. The number of surgeries is growing every day and many questions have emerged regarding the safety of surgical anesthesia, especially in the age extremes (infants and elder). Several studies suggesting the neuroprotective effect of anesthetics and others suggesting neurotoxic effect have been conducted and the controversies only increase [1].

Nearly two centuries after the first report of ether use as an anesthetic, the general anesthetic's mechanisms of action are not fully understood. It is known that they act by binding $\mathrm{GABA}_{\mathrm{A}}$ and NMDA receptors in certain brain regions. The connection to $\alpha 2$-agonist receptors in the locus coeruleus (LC) also causes sedation, however without reaching a deep level of hypnosis. However, the mechanisms by which neural networks operate to produce the anesthetic state are still unknown. [2]

What is certain is that some anesthetics act by stimulating the inhibitory GABA receptor while oth- ers inhibit the excitatory NMDA receptors and when the drugs act along the locus coeruleus their effect is potentiated, but they are unable to produce anesthesia alone. [2]

The halogenated have a more recent origin. The halothane had its clinical use released in 1956 and the isoflurane in 1981. They were all released very recently and the same way that we do not fully understand the mechanism of action of these drugs, we also do not know their long-term deleterious effects. [3]

It was revealed that general anesthesia would be a reversible state of unconsciousness and insensitivity induction that made possible the performance of surgical or diagnostic procedures and at the end the exposed individuals return to their initial state without any physiological or structural deficit.

Studies in laboratory animals suggest the possibility of deficits beyond the intraoperative. Especially in both of the age extremes, the exposure to general anesthetic may induce neuroapoptosis in specific brain regions, especially in neurons that are under development and accelerated synaptogenesis. These results, however, cannot be transposed to humans. [4] 
However, several clinical trials are underway to try to clarify this question, and some are nearing completion.

Animal studies, using short periods of exposure to inhaled anesthetics in subclinical doses and followed by inducted ischemia, has suggested neuroprotective effect of these drugs. However, more recent studies with therapeutic doses of inhaled anesthetics and for longer periods, has shown neurotoxicity. [5]

The studies that defend the ischemic preconditioning of inhaled anesthetics suggest their action decrease the metabolic rate of the brain, reducing the consumption of oxygen and probably increasing the release of nitric oxide. Those supporting the neurotoxicity, claim that there is an increase of neuroapoptosis triggered by the increased production of caspases, in addition to structural damage of neural cell in the cytoskeleton. Even studies in experimental animals are controversial. [4-8]

This question goes beyond, coming to the suggestion or not of the use of inhaled anesthetics in subtherapeutic doses for organ donors with brain death. Some defend the use of inhaled anesthetic, particularly isoflurane, suggesting its protective effect on ischemic preconditioning of the selected organs. $[5,6]$

Thus, the question is: Can general anesthetics in children lead to learning disorders? Thus, the objective was to describe the current studies about learning disabilities and cognitive dysfunction related to exposure to general anesthetic in children.

\section{Method}

This is a systematic review, performed from search in PubMed database using the keywords "general anesthetics," "neurotoxicity", "children", "young child" and "pediatric", it has as inclusion criteria, articles from the last five years; original articles with full access or only summaries; articles with the keywords in the title; in english, review articles and studies in humans.

The exclusion criteria eliminated studies performed in experimental animals, stem cells or the ones that focused on side effects of other substances on the central nervous system, such as alcohol or drugs; as well as studies involving different anesthetic techniques of general anesthesia and studies that were in languages other than English.

\section{Results}

Initially, the search resulted in 108 articles, of which 27 met our search criteria. 81 were excluded and the reasons were: 34 repeated references, 6 regional anesthesia, 30 other subjects, 5 stem cells, 5 animal studies, 1 case report (Figure 1).

Table 1 summarizes the most important aspects of each selected article, the main author and a brief description of the sample.

\section{Discussion}

Among the articles found, only one corresponded to a retrospective cohort and another to a clinical trial. All the rest were review articles. Two large clinical studies are in progress, but they still have no conclusive results, the PANDA study and the GAS study. The latter is expected to be finished in 2015 . However, they are aimed at assessing the vulnerability to general anesthetics in healthy children, ASA I and II, and their results cannot be extrapolated to children with comorbidities. [7,11]

It is interesting to observe that there is no significant amount of new clinical studies. However there are many review articles, reinforcing the concern that the topic brings up and the difficulty of preparing drawings that bring significant results, besides the ethical issues involved. The results of cohort studies are limited in their clinical applicability. 


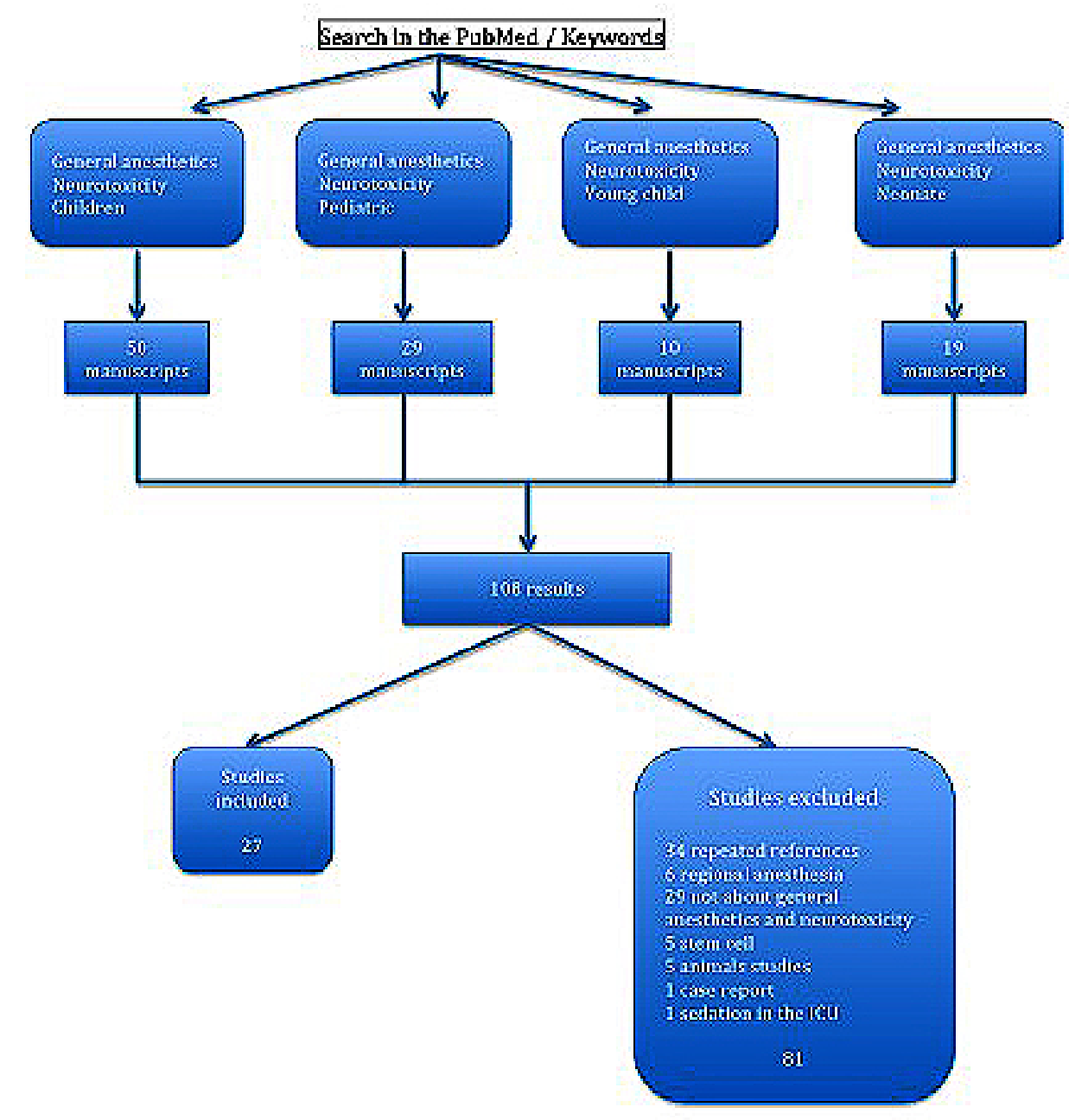

Figure 1. Flowchart representing the number of selected items in each search.

\section{Mechanisms of neurotoxicity}

General anesthetics induce neuroapoptosis. This effect is observed especially when there is the use of associated agents that act at different receptors, $\mathrm{GABA}_{\mathrm{A}}$ and NMDA. [9] Another associated factor is the exposure in periods occurring more intense activity of neuronal development, as synaptogenesis, resulting in memory and learning disorders. [10]

Apoptosis can be induced by several mechanisms with the final pathway as the formation of caspases, main substances responsible for cell death. The intrinsic pathway begins with the reduction of the anti-apoptotic proteins starting from BCL-2 (B cell lymphoma 2), followed by the increase of mitochondria permeability and cytoplasmic release of cytochrome $C$ and consequently, caspase-9 and caspase-3, resulting in cell death. [11]

Upon activation of the intrinsic pathway, there is the formation of the death-inducing signaling complex (DISC), with activation of caspase-8 and caspase-3, followed by cell death. [10]

There are two other important pathways in the outcome of neurocognitive disorders after general anesthesia which are: 1- pathway is dependent of brain-derived neurotrophic factor, which leads to induction of Trk-dependent pathway and P75 NTR (important inducers of apoptosis). 2- Pathway of neuronal cell destruction that results in decreased density of neurons in specific regions of the cerebral cortex. [10-12] 
Table 1: related articles

\begin{tabular}{|c|c|c|}
\hline Authors & Journal & Sample \\
\hline $\begin{array}{c}\text { Sinner B. et al. } \\
\mathbf{2 0 1 4}\end{array}$ & Anaesthesia & Review article \\
\hline $\begin{array}{c}\text { Bartkowska- } \\
\text { Sniatkowska et } \\
\text { al. 2014 }\end{array}$ & $\begin{array}{c}\text { Anaesthesiology } \\
\text { Intensive Therapy }\end{array}$ & Review article \\
\hline $\begin{array}{c}\text { Yan J. et al. } \\
\mathbf{2 0 1 4}\end{array}$ & $\begin{array}{c}\text { J Neurosurg } \\
\text { Anesthesiol. }\end{array}$ & Review article \\
\hline
\end{tabular}

\section{Garcia Guerra \\ G. et al. 2014 \\ Paediatr Anesth}

Olsen E.A. et al. 2013
Anaesthesiol
Cohort of 91 children under 6 weeks of age and subjected to cardiac surgery.

Review article
Review article

Davidson A et
al. 2013 $\quad$ Clin. Perinatol Review article

\begin{tabular}{|c|c|c|}
\hline $\begin{array}{c}\text { Jevtovic- } \\
\text { Todorovic V. } \\
\mathbf{2 0 1 3}\end{array}$ & Mol. Neurobiol & Review article \\
\hline $\begin{array}{c}\text { Sinner B. et al. } \\
\mathbf{2 0 1 3}\end{array}$ & Anaesthesist & Review article \\
\hline $\begin{array}{c}\text { Hays SR et al. } \\
\mathbf{2 0 1 3}\end{array}$ & J. Urol. & Review article \\
\hline $\begin{array}{c}\text { McCann ME et } \\
\text { al. }\end{array}$ & $\begin{array}{c}\text { British J. of } \\
\mathbf{2 0 1 2}\end{array}$ & Anaesth. \\
\hline $\begin{array}{c}\text { Byrne MW et al. } \\
\mathbf{2 0 1 2}\end{array}$ & $\begin{array}{c}\text { J Neurosurg } \\
\text { Anesthesiol }\end{array}$ & Review article \\
\hline
\end{tabular}

\section{Vutskits L et al. 2012}

Paediatri Anaesth

Review article

\begin{tabular}{c|c}
$\begin{array}{c}\text { Vlisides P et al. } \\
2012\end{array}$ & Curr Pharm Des. \\
\hline Jevtovic- & \\
Todorovic V & Curr Pharm Des. \\
2012 & \\
\hline
\end{tabular}

\section{Main findings}

Animal studies suggest strong evidence of neurotoxicity of general anesthetics. Moreover, this data can note be extrapolated to human.

Evaluated in the literature, the neuroprotective, neurotoxic and anti-inflammatory effects caused by ketamine administered in various doses and in the presence and absence of the noxious stimuli.

The use of chloral hydrate was associated with poorer performance on the intelligence quotient test and the use of benzodiazepines resulted in lower scores on visual and motor integration test.

Evaluates retrospective studies in children under 3 years children exposed to anesthesia and associates them to greater risk of learning disorders after repeated exposure. However, points out that the current data are insufficient to change the current practice

General anesthetics in animal models are responsible for accelerating the neuroapoptose, however, there is insufficient data to extrapolate these data to humans. Evidence suggests that the inadequate treatment of pain leads to intense stress and neurotoxicity.

Reaffirms the existing evidence on the neurotoxicity of general anesthetics in animals. And fetches data in the literature to help develop neuroprotective strategies.

It analyzes the current data highlighting the prospective studies in progress.

Repeated exposure to anesthetics and early life result in cognitive disorders.

Discusses the biases associated with retrospective studies and the lack of sufficient evidence to associate anesthetic neurotoxicity

Biannual symposia of The Pediatric Anesthesia NeuroDevelopment Assessment research group at Columbia University Medical Center Department of Anesthesiology evaluating new evidence of neurotoxicity.

Debate studies in experimental animals and clinical studies as well as the limitations of extrapolating the findings to clinical practice.

Examines current data on neurotoxicity induced by anesthetics and questions the potential implications of this association.

Lists the neurotoxic effects of general anesthetics to age, being more likely in the elderly and children during that synaptogenesis occurs 


\begin{tabular}{|c|c|c|c|}
\hline Authors & Journal & Sample & Main findings \\
\hline Holtby HM 2012 & Future Cardiol & Review article & $\begin{array}{l}\text { Describe the causes of neurodevelopmental impairment in } \\
\text { children with heart disease }\end{array}$ \\
\hline $\begin{array}{l}\text { Ward CG et al. } \\
\qquad 2012\end{array}$ & Pharmacol Res & Review article & $\begin{array}{l}\text { Neurotoxicity was observed in young animals, however, is } \\
\text { not possible to correlate the data to humans. }\end{array}$ \\
\hline $\begin{array}{l}\text { Bhutta AT et al. } \\
\qquad 2012\end{array}$ & $\begin{array}{l}\text { Pediatr Crit Care } \\
\text { Med }\end{array}$ & $\begin{array}{l}\text { Randomized clinical } \\
\text { trial }\end{array}$ & $\begin{array}{l}\text { Found no evidence of neuroprotection or neurotoxicity in the } \\
\text { study. }\end{array}$ \\
\hline $\begin{array}{l}\text { Thomas J et al. } \\
\qquad 2011\end{array}$ & Anesth Analg & Review article & $\begin{array}{l}\text { Evaluates more recent studies of behavioral disorders } \\
\text { in children under } 3 \text { years following exposure to general } \\
\text { anesthetics. }\end{array}$ \\
\hline $\begin{array}{l}\text { Davidson AJ } \\
\quad 2011\end{array}$ & Paediatr. Anaesth & Review article & $\begin{array}{l}\text { Evaluates the evidence from studies in animals and humans } \\
\text { neurotoxicity general anesthetics. }\end{array}$ \\
\hline Sun L 2010 & $\begin{array}{l}\text { Britsh J of } \\
\text { Anaesthes }\end{array}$ & Review article & Assesses the ongoing clinical studies PANDA and GAS. \\
\hline $\begin{array}{l}\text { Brusseau R et } \\
\text { al. } 2010\end{array}$ & Early Human Dev & Review article & $\begin{array}{l}\text { Discusses the importance of suppression of responses to } \\
\text { stress. }\end{array}$ \\
\hline $\begin{array}{l}\text { Mons F et al } \\
\quad 2010\end{array}$ & $\begin{array}{l}\text { Ann Fr Anesth } \\
\text { Reanim }\end{array}$ & Review article & $\begin{array}{l}\text { Review the safety issues of anesthetic agents on the } \\
\text { developing brain.. }\end{array}$ \\
\hline
\end{tabular}

\section{Clinical evidences}

The published clinical studies that were focused on this topic are all retrospective cohorts, with their limitations. The first evaluated a cohort of children under four years old, anesthetized with halothane and nitrous oxide, between 1976 and 1982, and the outcome was the learning disability in mathematics, language or reading. Any of the three were seen as learning disabilities, inadequate clinical situation, as each of these functions is controlled by specific brain regions. [13, 23,24]

Another cohort analyzed children under four years old, who received multiple exposures to anesthesia and surgery and were compared to an unexposed group. A higher incidence of behavioral disorders and attention deficit hyperactivity disorder was found in children who received general anesthesia. [14]

A recent study using the Taiwan database examined 5197 children born between 2001 and 2007 who received single or repeated exposure to general anesthesia and compared to a control group of 20,788 individuals who were not exposed. They sought a possible association between exposure to anesthesia and development of disorders related to autism and found no differences between the groups. [15]

There is a strong association between duration of anesthesia and multiple exposures with learning and behavior disorders. [16]

Study realized with 1143 pairs of identical twins in the Netherlands, with the only variable as the administration of general anesthesia before three years old of age in one of the groups, did not observe any difference in cognitive problems and learning disorders between groups. [16, 17,19]

In Denmark and the Olmsted County, children undergoing surgery using general anesthesia before completing four years old showed no significant difference between groups. [17] 
DiMaggio, analyzing a database of the city of New York, has selected 304 children born between 1999 and 2005, submitted to surgical procedures before completing three years old and previously healthy. DiMaggio used as the control group, 10 146 children of the same database that have not gone through surgery and found an odds ratio of 1.7 for the development of behavior disorder associated with anesthesia. [18,21]

There is evidence that the $\alpha 2$-agonists have antiapoptotic properties in animal models, decreasing the formation of caspase-3 in the brains of newborn rats, when administered to anesthetized pregnant rodents with propofol. [22,25]

After these findings, even with controversial results in relation to the actual harmful effects of general anesthetics in humans, the FDA (Food and Drug Administration) and the IARS (International Anesthesia Research Society) have established a partnership that created the SmartTots (Strategies for Mitigating Anesthesia- Related Neurotoxicity in Tots). [26]

A team of experts in the matter was gathered and in 2012 they prepared the first agreement to be followed until new studies point more conclusive results. The group met again in 2014 and updated consensus, suggesting the avoidance of surgical procedures in children younger than three years old, except in emergency situations. They added the importance of new studies in animals and randomized clinical trials in the search for more conclusive evidence. [26]

\section{Conclusion}

There is currently little evidence and much expectation regarding the neurotoxicity mediated by general anesthetics. Few original articles were published in the last five years; however the topic was widely discussed in some reviews.
At the moment, it is not possible to say that the damage caused by anesthetics in animals can be replicated in humans. However, because of the severity of the outcome, the FDA recommends avoiding anesthesia and surgery in children under three years old, at least in those who are not in an emergency situation.

\section{References}

1. Viana JT. Tratado de Anestesiologia, SAESP. 7 ed. São Paulo: Editora Atheneu, 2011;(1)3-13

2. Garcia PS, Kolesky SE, Jenkins A. General Anesthetic Actions on GABAA Receptors. Current Neuropharmacology, 2010.8:2-9

3. Chiao S, Zuo Z. A Double-Edge sword: Volatile anesthetic Effects on the neonatal Brain. Brain Sci. 2014;4:273-94

4. Wei H, Inan S. Dual effects of neuroprotection and neurotoxicity by general anesthetics: role of intracellular calcium homeostasis. Prog Neuropsychopharmacol Biol Psychiatry. 2013.2;47:156-61.

5. Boutin C, Vachiéry-Lahaye F, Alonso S, Louart G, Bouju A, Lazarovici S, Perrigault PF, Capdevila X, Jaber S, Colson P, Jonquet O, Ripart J, Lefrant JY, Muller L. Anaesthetic management of brain-dead for organ donation: impact on delayed graft function after kidney transplantation. Ann Fr Anesth Reanim. $2012 ; 31(5): 427-36$

6. Yan J, Jiang H. Dual effects of ketamine: neurotoxicity versus neuroprotection in anesthesia for the developing brain. J Neurosurg Anesthesiol. 2014;26(2):155-60

7. Sinner B., Becke K. and Engelhard K. General anaesthetics and the development brain: an overview. Anaesthesia. 2014;69 1009-22

8. Bartkowska-Śniatkowska A, Rosada-Kurasińska J, Zielińska $M$, Bienert $A$. Do we really know the pharmacodynamics of anaesthetics used in newborns, infants and children? A review of the experimental and clinical data on neurodegeneration. Anaesthesiology Intensive Therapy. 2014, 46(2)101-8

9. Reddy SV. Effect of general anesthetics on the developing brain. J Anaesthesiol Clin Pharmacol. 2012;28(1):6-10

10. Jevtovic-Todorovic $V$. Developmental synaptogenesis and general anesthesia: a kiss of death? Curr Pharm Des. 2012;18(38):622531

11. Vlisides $P$, Xie Z. Neurotoxicity of general anesthetics: an update. Curr Pharm Des. 2012;18(38):6232-40

12. Morgan PG, Sedensky M. A new Phase in Anesthetic-induced Neurotoxicity Research. Anesthesiology 2011;114(1):10-1

13. Sun L. Early childhood general anaesthesia exposure and neurocognitive development. British J of Anaesth. 2010; 105 (S1):i61-i8 
14. Vutskits L, Davis PJ, Hansen TG. Anesthetics and the developing brain: time for a change in practice? A pro/con debate. Pediatric Anesthesia. 2012; 22:973-80

15. Loepke AW, Hansen TG. Is this your (paediatric patient's) brain on (anaesthetic) drugs? The search for a potential neurological phenotype of anaesthesia-related neurotoxicy in humans. Europ J of Anaesth. 2015, 32:289:300

16. McCann ME, Soriano SG. Perioperative central nervous system injury in neonates. British J of Anaeth 2012;109(s1):i60-i67

17.Thomas J, Crosby G, Drummond JC, Todd M. Anesthetic Neurotoxicity: A difficult dragon to slay. Anesth Analg 2011; 113(5):969-72

18. Davidson AJ, McCann ME, Morton NS, Myles PS. Anesthesia and Outcome after Neonatal Surgery. Anesthesiology 2008;109:941-4

19. Bartels M, Althoff RR, Boomsma DI. Anesthesia and cognitive performance in children: no evidence for a causal relationship. Twin Res Hum Genet 2009;12:246-53

20. Ward CG, Loepke AW. Anesthetics and sedatives: Toxic or protective for the developing brain? Pharmacol Res. 2012;65:2714

21. Stratman G. Neurotoxicity of anesthetic Drugs in the Developing Brain. Anesth Analg. 2011;113(5):1170-9

22. Li J, Xiong M, Nadavaluru PR, Zuo W, Ye JH, Eloy JD, Bekker A. Dexmedetomidine Attenuates Neurotoxicity Induced by Prenatal Propofol Exposure. J Neurosurg Anesthesiol. 2015

23. Deng $M$, Hofacer RD, Jiang $C$, Joseph $B$, Hughes EA, Jia B, Danzer SC, Loepke AW. Brain Regional vulnerability to anaesthesiainduced neuroapoptosis shifts with age at exposure and extends into adulthood for some regions. Britshi J of Anaesth 2013.

24. Rappaport B, Mellon RD, Simone A, Woodcock J. Defining safe use of anesthesia in children. N Engl J Med. 2011;364:1387-90

25. Yoles E, Wheeler LA, Schwartz M. $\alpha 2$-Adrenoreceptor Agonists Are Neuroprotective in a Rat Model of Optic Nerve Degeneration. Invest Ophthalmol Vis Sci. 1999;40:65-73

26. Rappaport BA, Suresh S, Hertz S, Evers AS, Orser BA. Anesthetic Neurotoxicity - Clinical implications of Animal Models. N Eng J Med. 2015;372(9):796-7.

\section{Comment on this article:}

\section{(f) $[$ in $8+\mathbf{S} P$}

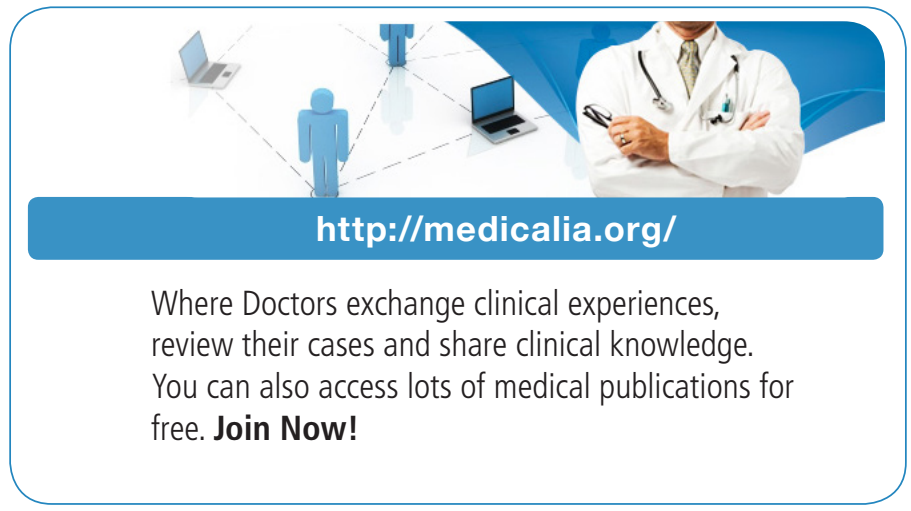

\section{Publish with iMedPub}

http://www.imed.pub

Neurology and Neuroscience (jneuros.com) is a hybrid, peerreviewed journal that considers articles concerned with any aspect of clinical neurosciences such as neurology, psychiatry and neurosurgery, as well as basic research on neuroscience where neurologists and neuroscientists publish together. 